\title{
Individualism in the United States in the 19th Century in Terms of Sociolinguistics on the Example of Works by R. W. Emerson and H. D. Thoreau*
}

\author{
Indywidualizm w Stanach Zjednoczonych w XIX w. \\ $\mathrm{w}$ ujęciu socjolingwistycznym na przykładzie prac \\ R. W. Emersona i H. D. Thoreau \\ Natalia PODLECKA ${ }^{1}$ \\ Ateneum-Szkoła Wyższa w Gdańsku
}

\begin{abstract}
Individualism is today a part of the American identity. Due to the short history of the U.S. the American people were in need to create their own customs and traditions. That is why there are manifold philosophical and political writings involving the characteristics of an American and views on ideal versions of the young country. However different those views may be, there are motifs that repeatedly occur over time and individualism is one of the most popular themes. This research discusses the involvement of two representatives of the Transcendental Movement in the U.S., Ralph Waldo Emerson and Henry David Thoreau, in the formation of American ethos. The study is based on the analysis of the essay "Self-Reliance" by Emerson and fragments
\end{abstract}

\footnotetext{
* This article was written on the basis of the master's thesis entitled "The Individual's Rebellion Against Society in American Thought and Literature (Ralph Waldo Emerson, Henry David Thoreau, Jack Kerouac, J.D. Salinger, Douglas Coupland)", defended in 2013 at the University of Gdańsk.

1 (C) https://orcid.org/0000-0002-3329-782X

Ateneum-Szkoła Wyższa w Gdańsku, Wydział Neofilologiczny

n.podlecka@ateneum.edu.pl
} 
of Thoreau's book Walden and his essay "Civil Disobedience". Not only is the substance of the texts is analysed, but also the vocabulary choices and their possible consequences.

Keywords: individualism, sociolinguistics, American ethos, transcendentalism, expressive language

\section{Streszczenie}

Indywidualizm jest dziś częścią amerykańskiej tożsamości. Ze względu na krótką historię Stanów Zjednoczonych naród amerykański musiał stworzyć własne zwyczaje i tradycje. Dlatego istnieje wiele pism filozoficznych i politycznych dotyczących cech Amerykanina i poglądów na temat idealnych wersji młodego kraju. Jakkolwiek różne mogą być te poglądy, są motywy, które wielokrotnie pojawiają się w czasie, a indywidualizm jest jednym z najpopularniejszych tematów. Niniejsze badanie dotyczy zaangażowania dwóch przedstawicieli ruchu transcendentalnego w USA, Ralpha Waldo Emersona i Henry'ego Davida Thoreau, w kształtowanie amerykańskiego etosu. Badanie opiera się na analizie eseju „Self-reliance” Emersona oraz fragmentów książki Thoreau Walden i jego eseju „Civil Disobedience”. Analizowana jest nie tylko treść tekstów, ale także dobór słownictwa i jego możliwe konsekwencje.

Słowa kluczowe: indywidualizm, socjolingwistyka, amerykański etos, transcendentalizm, język ekspresyjny

\section{Introduction}

In the 1830s, a group of intellectuals interested in literature, philosophy and religion emerged in Massachusetts, in the United States. Their interests were grounded in Romanticism, however, they managed to create a unique group of thinkers and artists called Transcendentalists. They all believed in the significance of an individual and his or her development, as well as the transcendence of God and spirit in nature. They wanted to look beyond the material part of life and discover the value and potential of any individual. There were also many other aspects of life that concerned them. Michael Meyer (1986) in an introduction to Henry David Thoreau's Walden describes the group Thoreau also belonged to in the following manner: "The Transcendentalists were eclectic rather than systematic, any brief description of their views tends to be reductive" (p. 9). Meyer supports this claim of the Transcendentalists' diversity by bringing up examples of some of their representatives. There were people like George Ripley, who believed in "uniting the thinker with the worker" (Meyer, 1986, p. 11) and established a utopian community of Brook Farm. Ripley and his supporters lived there and worked collectively from 1841 to 1847. Another transcendentalist, Amos Bronson Alcott, tried a similar idea, however his Fruitlands were not that successful as it lasted only a year, from 1843 to 1844 . Others, like Thoreau 
or Ralph Waldo Emerson preferred less codified meetings, like those of the Transcendental Club, which took place in 1836-1840. Yet another way to express one's views, like in case of Margaret Fuller, for example, was the Dial, "quarterly journal of literature, philosophy, and religion," published since 1840 to 1844 . Transcendentalists looked for different ways to articulate their beliefs. As Meyer (1986) puts it:

Indeed, their primary activities were forms of self-expression rather than the kinds of social, economic, or political actions that the bustling nineteenth century would have been likely to comprehend. They discussed, wrote, and lived their ideas instead of inventing machines, initiating commercial enterprises, or introducing legislation. (p. 10)

That does not mean that Transcendentalists were not interested in any concerns of their fellow citizens. Many of them openly shared their political views with their audience. Alcott was an abolitionist and he advocated women's rights. Theodore Parker, also an abolitionist, was a reforming minister of the Unitarian Church. Fuller is often called the first feminist, even though her postulates were largely restricted to providing all American women with access to higher education. She also ran a series of lectures for women, proving they really had the right to study. Emerson wrote many essays on which he touched upon politics, while Thoreau, despite his appreciation for solitude, often voiced his concern with the political and social situation in the U.S.

This article explores the concept of an individual presented by two representatives of the Transcendentalists, Emerson and Thoreau. It starts with an analysis of Emerson's essay "Self-Reliance," published in 1841 in his collection Essays: First Series. Then I investigate Thoreau's writings, first Walden, published in 1854, and subsequently his famous political essay entitled "Civil Disobedience" first published in Elizabeth Peabody's Aesthetic Papers in 1849. Based on these works I examine how important the individual was for the Transcendentalists, and how their writing and philosophy influenced the recognition of individualism as a characteristic of an American citizen. Furthermore, the article will explore the language used by these authors and demonstrate the most significant and powerful phrases involving the theme of American individualism.

\section{Individualism by Ralph Waldo Emerson}

There are many subjects addressed by Ralph Waldo Emerson. According to Saul K. Padover (2012), "no account of American thought - be its emphasis 
on philosophy or theology or society or politics - can be complete without reference to Emerson" (p. 334). It is hard to deny that, as his many essays discuss manifold aspects of the American life in the 19th century. Alfred Kazin (n.d.) called him "the teacher of the nation" (as cited in Padover, 2012, p. 334), which also cannot be denied as Emerson's words are read and repeated till this day. His importance is especially apparent in the U.S., as he participated in the creation of the American character by rejecting the importance of European thought and culture. What is more, he believed that American citizens should not only stop relying on tradition and studies of their predecessors, but also start believing in the value of their own enterprise. In his essay, "Self-Reliance," Emerson explains what an individual and his or her power is, and how to become a self-reliant person.

Emerson has a clear vision of what an individual is capable of and why each citizen is more important than the society in which he or she lives. As the title "Self-Reliance" suggests, the main idea of the text is that each person should rely only on his or her thoughts and experiences. He states that we should not ask others how to live, we should trust our own conscience and common sense. He goes as far as to say that "[t]o believe your own thought, to believe that what is true for you in your private heart is true for all men, - that is genius" (Emerson, 2009, p. 26). Not only does he believe that we should act accordingly to our instincts, but he claims that such instincts are universal. What is more, he uses a powerful statement, using the word 'genius', which has a few distinctive connotations to the context of American individualism. Firstly, according to Merriam-Webster Dictionary, the word 'genious' can be understood as:

3 a: a peculiar, distinctive, or identifying character or spirit

// the genius of our democratic government

$\mathrm{b}$ : the associations and traditions of a place

$[\ldots]$

$5 \mathrm{a}$ : a single strongly marked capacity or aptitude [...]

b : extraordinary intellectual power especially as manifested in creative activity

c : a person endowed with extraordinary mental superiority (Merriam-

Webster Dictionary, n.d.)

If this interpretation should be followed, Emerson's statement can be understood as an identification of a true American spirit, that is a quality that distinguishes a person living in the U.S. from all other nations in the world. That was significant at that time, when the U.S. was still a very young country 
and despite the strong belief of many of the American citizens in the uniqueness of their nation, they had not been recognized as such by others yet. Another part of the given above dictionary entry states that 'genius' can also be explained as "the associations and traditions of a place", which also confirms the need the Americans had at the time to create a country that would be recognized not as colonies and descendants of predominantly European origins, but as a separate nation, with its customs and culture. Furthermore, by declaring self-reliance a distinctively American treat, Emerson participated in creating the national identity. This can be seen as paradoxical to some extent, as he was undeniably stressing the value and strength of an individual, and not the society. What is more, he wrote about the superiority of a singular human being above the system or society in which we live. He criticized the latter as a main source of this evil which he called conformity and explained the idea of self-reliance in following words:

Society everywhere is in conspiracy against the manhood of every one of its members. Society is a joint-stock company, in which the members agree, for the better securing of his bread to each shareholder, to surrender the liberty and culture of the eater. The virtue in most requests is conformity. Self-reliance is its aversion. (p. 29)

Society was presented by him as a force that forbids its members to live independently and self-reliance was his solution to this problem. In the accommodation to the surrounding world and the expectations of society and especially authorities, Emerson saw the loss of power and integrity (Padover, 1986, p. 334). He expanded this idea, by denying the prominence of established laws, and claiming that the basic ethics is born within ourselves. Doing anything against one's conscience is wrong, and following it is right (Emerson, 2009, p. 29). He warned his readers against believing in conventions and established rules of behaviour that are imposed on us almost since we are born. One can take them into consideration, however, the integrity of one's conscience should be the priority in making any decisions. Emerson explained his mistrust of society with the statement that "[s]ociety never advances" (p. 47). By using the adverb 'never' he gave a sense of finality of the statement. That does not mean that society does not change. It does, however, each change is not for better, as we tend to believe. Any alteration to our world must be paid with a loss of something else. Emerson gave many examples of an evolution, but there are two, which depict his idea in an obvious and understandable manner. Probably the most vivid one is the example of the invention of a watch. Thanks to this innovation we can measure time 
more precisely, however, since we started using watches we lost our ability to tell time by looking at the sun. Another comparison makes Emerson's view on society even clearer, as he states that "society is a wave," meaning that even though we can see it moving and changing its shape, there is no alteration to its main body (p. 48).

Next to discussing dangers to each person, such as conformity and social conventions, Emerson instructed his readers on how to become self-reliant. He explained that everyone should study history and literature only as sources of examples of individuals, like "Moses, Plato and Milton" (p. 26), who came up with great ideas without any relation to their customs or conventions. Emerson warns his reader that "imitation is suicide" (p. 27), meaning that one should only search into oneself to know what to do. He puts stress on the fact that we should not use the teachings of history and art as lessons on how we should act. Using the word "suicide" makes the claim stronger in its connotations, as it makes clear that, to Emerson, copying or mimicking someone was as serious and mortifying as killing oneself. This shows the importance of cutting all ties connecting the U.S. with Europe in the process of creating the new nation. Furthermore, he listed other factors influencing a person's opinion, such as other people. It should be noted that humans are social creatures and, in most cases, they cannot live self-sufficiently and without any recognition of their neighbours. Nevertheless, Emerson's point here was that the fact that we live among others and cooperate with them in one way or another, does not mean that we should in any way copy them. That may not be that easy, as there are many social rules and conventions that for some people are undeniable. However, Emerson recognized the problem and the difficulty in resolving it, as the number of influences in our lives is so great that having an unbiased opinion appears almost impossible. On the other hand, why should we trust more in someone else's statement than in ours? It may appear easier to take for granted what was said before and in some respects it surely is. However, Emerson urged his audience to stop and consider if that is really right and if our actions and statements reflect our beliefs. It should not matter to us what others do or say, as long as we are fully conscious of our thoughts and actions. Conforming to any opinion or to any group is like living in a lie - one cannot be honest if he or she only repeats somebody else's thoughts (Emerson, 2009, p. 31). It does not mean that whatever someone else thinks is wrong and that we should defy any statement made by others. It means that we should first think for ourselves and be able to question what others say. We may agree with them or not, but the important aspect is that the decision should be made only by us. What is more, Emerson 
states, that it is not good to be too consistent in one's beliefs, as he says that "[w]ith consistency a great soul has simply nothing to do" (p. 33). That means we should always challenge not only others, but also ourselves. This is crucial, as thanks to such an attitude, one is more likely to evolve and learn. Emerson stressed that we should rely on our intuition, which is our wisdom, whereas all formal education we get in our lives he called "tuition" (p. 36). According to him, we instinctively know what to do and the truth is always inside us. Additionally, Emerson believed that to achieve self-reliance we must expand our actions beyond ourselves. Only through the transformation of all the spheres of our lives, such as religion, education and personal habits, can we achieve the true self-reliance (p. 43).

Emerson urged his readers to stay true to themselves and not to succumb to the voice of the majority. He gave his readers a great motivation to believe in themselves and their abilities by convincing them that each had sufficient wisdom to take their decisions. What is more, Emerson contributed to the creation of American identity, especially to the origin of American individualism, which, thanks to him, among others, is considered one of the main American traits. The vocabulary he uses is definite and clear, with numerous emphasis on the significance of the individual thought. What is more, the power of praising others cannot be underestimated. For many Emerson's rhetoric can be alluring, as statements about the power of individual thought give the readers reason to believe that they are always right. This is a dangerous assumption, and could be a great misunderstanding of the author's intention. That is why self-improvement and questioning not only others, but oneself as well, are essential parts of Emerson's message. He did not have to wait long to see his influence on other people, as his fellow transcendentalist, Henry David Thoreau, had proved.

\section{Individualism by Henry David Thoreau}

Today Henry David Thoreau's work belongs to the literary canon in the U.S., however during his life, he did not attract considerable attention. Even though he befriended Emerson, who was fairly popular, at least in Massachusetts, Thoreau's words gained popularity with later generations. Many of his contemporaries did not approve of his actions and considered him eccentric. However, his only fault was following Emerson's words of self-reliance and living by them. The first instance supporting this statement is Thoreau's two years in the woods by Walden Pond, described by him in Walden. He built 
the cabin in which he lived, he worked only to fulfill his basic needs, and the rest of the time he spent on writing and exploring the fauna and flora surrounding him. The second instance is his essay entitled "Civil Disobedience" in which he shares with the reader his understanding of non-conformism and his politics of performing conscience. Moreover, in the essay, Thoreau indicated the faults of the American government and explained how one should act in order to remain true to one's self. Like Emerson, he contributed to the creation of the ethos of American individualism.

\subsection{Individualism in practice $-\mathrm{H}$. D. Thoreau and Walden}

In Walden, Thoreau presented his idea of a non-violent rebellion against the system. He explained his departure to the woods in the chapter "Where I Lived, and What I Lived For." He stated that he wanted to live intentionally and his retreat into the wild could be an opportunity to learn more about general facts of life. He wanted to learn if life is good or bad by his experience and he considered removing himself from the social bounds as the best way of achieving it. Additionally, he intended to share his experience with the world, which he did through writing (p. 135). He moved to his cabin on July 4, 1845. He described the process of preparing it in his first chapter "Economy," where he gave a detailed account of what his cabin was built of and how much did it cost. He used mostly second-hand materials and designed the house in a rather Spartan manner. While giving an account of his achievement, Thoreau inquires why it is not common for other men to build their own houses. He believed that unfortunately people often let others decide what is best for them. He says that "no doubt another may also think for me; but it is not therefore desirable that he should do so to the exclusion of my thinking for myself' (p. 89). He does not use strong and definite words here, as the expression 'not desirable' is a rather delicate one, however clearly an individual thought is significant in Thoreau's philosophy. What is more, the whole cost of the cabin was little over $\$ 28$, which even in the 19th century was not that much. He compared his situation to that of a student who could use the annual rent to build him- or herself a house for the rest of his or her life (p. 92). He explored the situation of an American student further, by questioning the logic of payment for accommodation in comparison with much more valuable, yet free, association with "the most cultivated of his contemporaries" (p. 93). That also proves that Thoreau did not aspire to gain material wealth, and in that way he denied the common American trend. Richard Drinnon (1991), in his essay "Thoreau's Politics of the Upright Man," 
states that "Thoreau saw clearly that the accumulation of wealth really leads to the cheapening of life" (p. 373). Perhaps it did not involve all American citizens at the time, but pursuing material wealth was definitely on the agenda of the majority of Americans. New waves of immigration, the development of the eastern colonies, the westward expansion - all those are proofs of the search for wealth that motivated people across the U.S. and not only. The main way to achieve success, according to most, was to get rich. Thoreau's attitude was completely different. Even though he was born into a rather wealthy family, money did not gain much significance for him. He worked only to fulfill his basic needs, such as food and that only if he was not able to grow it by himself. That is why he built his cabin only to satisfy his needs.

Apart from the defiance of social norms, there is also criticism of the government and society in Walden. However, this issue is more deeply analyzed in "Civil Disobedience." The two texts are linked, as the situation that led to the writing of the essay happened while Thoreau lived by Walden Pond. He briefly described it in the chapter "The Village":

One afternoon, near the end of the first summer, when I went to the village to get a shoe from the cobbler's, I was seized and put into jail, because, . . I I did not pay a tax to, or recognize the authority of, the state which buys and sells men, women, and children, like cattle at the door of its senate-house . . But, wherever a man goes, men will pursue and paw him with their dirty institutions, and, if they can, constrain him to belong to their desperate oddfellow society. (Thoreau, 1986, p. 218)

Thoreau was imprisoned on July 24 or July 25, 1846, for refusing to pay a poll tax. He justified his disobedience with the immoral acts of the government. In the passage above Thoreau openly criticizes the government, in general for its need for controlling people and in particular for the immorality of slavery. He was unable to obey an institution that allowed taking advantage of a group of people for the betterment of another group. With the parallel to the life of cattle, he made his position on slavery obvious and his criticism of the government does not leave any doubts about his attitude. He also called institutions "dirty", which not only separates an individual from the society, but also places the government lower on a scale of importance, and what is even more important, adds a negative connotation to the concept of the authority. Finally, Thoreau claimed that to become a compatible part of the society, one must be restrained, so in result by becoming part of the group individuality and freedom disappears. He used another forceful phrase here, that is: "their desperate odd-fellow society". The use of the possessive 
pronoun "their" clearly indicates that the author separates himself from the society and did not consider himself as a part of it. The adjective "desperate" has negative connotation and also shows a lack of respect on Thoreau's part. This is strengthened even more with naming the authorities and people following them "odd-fellow." Using just one phrase Thoreau makes the society and the government inferior to the individual, thus strengthening the importance of individualism in American reality.

\subsection{Individualism and questioning the government $-\mathrm{H}$. D. Thoreau and "Civil Disobedience"}

The imprisonment incident inspired Thoreau to write an essay devoted to citizens' rights and duties. In "Civil Disobedience" he criticized not only the government for abusing its power, but also the American citizens for underestimating theirs. He argued that people concentrate too much on collecting wealth and property, and their fear of losing it prevents them from any action that could disturb the status quo. Most people, according to Thoreau, are content with the illusion of safety that the state offers to those who obey its laws. He states that: "For my own part, I should not like to think that I ever rely on the protection of the State. But, if I deny the authority of the State when it presents its tax-bill, it will soon take and waste all my property, and so harass me and my children without end" (Thoreau, 1986, p. 400). The balance between the individual and the state can be easily shattered, as Thoreau observed. There is no place for any dialogue between the two, as any disobedience to the rules established by the state ends up in losing the protection that the government is supposed to provide. Theoretically, American people in the 19th century knew that the government's power derived from them, and that they could abolish it whenever they would feel endangered by its actions. We know as much today. However, in practice we do not exercise this right just as people in Thoreau's times did not. We tend to underestimate the power of the individual and thus we give up before taking any action. Thoreau criticized his fellow citizens for that exactly. He blamed them for their passiveness. Even if they recognized the problem, all most of the people did was to seek blame in others and complain. "Civil Disobedience" was addressed to all the people who either see the problem and do nothing or do not see it at all. Thoreau tried to convince his reader that some action must be undertaken if anything was going to change. One of his proposals is what he called a "peaceable revolution." The phrase may sound like an oxymoron, however his explanation showed that it is not. In his view, if all 
of the majority of the taxpayers refused to pay taxes, the government could do nothing about it, because it would not be possible to put them all in prisons. He does not encourage any violent attacks on the government, instead he advocates his readers' common sense and seeks peaceful solutions of the problem. He explains that even though he is not satisfied with the state's doings, he wants "not at once no government, but at once a better government" (p. 402). Like Emerson, Thoreau understands the need of a gradual change connected with constant educating of American citizens so that they can learn how to be self-reliant and independent from external influences. However, Thoreau's views at the time were seen as radical ones. Richard Drinnon (1991) in his analysis of Thoreau's politics tries to decide whether we can call this nineteenth century writer an anarchist. What defines him as such is his belief in the higher law and "practice of individual direct action" (Drinnon, 1991, p. 369). The higher law doctrine means that any law established by people is inferior to the laws of nature. Recognizing and understanding those laws is, according to Drinnon (1991), "the logical last step of individual action" (p. 369). To simplify anarchism, according to these standards, is acting on what one privately believes is right. However, Drinnon also draws the reader's attention to the fact that many scholars preferred to call Thoreau an individualist, not an anarchist, as he did whatever he felt was right without any consideration of his neighbors. Others claim that he was a socialist, as he understood the importance of community. The lack of common ground on this subject is explained by Drinnon (1991) in the following words: "But the main obstacle to any clear cut identification of Thoreau's politics has been the uncertain shifting borders of anarchism, liberalism, and socialism in the nineteenth century and after" (p. 370). Therefore, any attempts on classifying Thoreau's political views are superfluous, especially in the context of individualism, which in its core means independence from any organized ideology. The fact that "Civil Disobedience" was quoted and referred to by many people fighting oppressive governments, like Mohandas Gandhi or Martin Luther King Jr., proves the strength and timelessness of Thoreau's message.

\section{Conclusions}

When thinking of a description of American character, one cannot omit the term individualism. As Gregory B. Markus (2001) stated in his research "American Individualism reconsidered": 
Regarding the United States, perhaps no core cultural value has received more attention over the years in both scholarly and popular literature than has individualism. Ever since Alexis de Tocqueville visited the United States more than 150 years ago, political observers have been fascinated by what they perceived to be the enduring centrality of individualistic values to the American ethos. (p. 403)

However, individualism would not be as important today if its value had not been praised by such influential writers and thinkers as Emerson and Thoreau. Their works contributed to the creation of the idea of a typical American citizen, or in their views, an ideal one. Perhaps not every citizen of the U.S. knows these writers, but the significance of the rights of the individual is understood by the vast majority. This can be seen in the analysis of political views of the Americans - "Forty years of research in political psychology indicates that most Americans most of the time do not deduce their issue attitudes or assessments of political leaders from enduring ideological principles such as liberalism, conservatism, libertarianism, or socialism." (Converse, 1964; Kinder, 1983; Neumann, 1986, as cited in Markus, 2001, p. 401). That is probably why Transcendentalism also did not evolve into a widespread movement, but despite that, its representatives were able to create notions more powerful and lasting much longer than ideologies tend to do. Using simple rhetoric, they gave power to the individual and gave people reasons to value their own strength and oppose the government whenever they feel threatened. As is the case of many phenomena in the U.S., this also has been used by people in situations which may appear extreme, like protests against restrictions due to the pandemic in 2020. The protesters also advocated their right as individuals to oppose their government's decisions on lock down and wearing masks. These demonstrations are still a controversy, as many protesters were reported to have fallen ill afterwards, which would suggest that their interpretation of the individual rights were taken one step too far. Nevertheless, individualism is undeniably a part of American reality and identity and both Emerson and Thoreau greatly contributed to its creation.

\section{REFERENCES}

Drinnon, R. (1962). Thoreau's Politics of the Upright Man. The Massachusetts Review, 4(1), 126-138. Retrieved August 2, 2020, from www.jstor.org/stable/25086956

Emerson, R. W. (n.d.). Self-Reliance. Ralph Waldo Emerson. Retrieved October 20, 2012, from https://emersoncentral.com/texts/essays-first-series/self-reliance/ 
Genius. (n.d.). Retrieved August 02, 2020, from https://www.merriam-webster.com/dictionary/ genius

Markus, G. B. (2001). American Individualism Reconsidered. Citizens and Politics, 401-403. https://doi.org/10.1017/cbo9780511896941.019

Padover, S. (1959). Ralph Waldo Emerson: The Moral Voice in Politics. Political Science Quarterly, 74(3), 334-350. doi:10.2307/2146273

Thoreau, H. D., \& Meyer, M. (1983). Walden and Civil Disobedience (Penguin American Library) (1st ed.). Penguin Classics. 
